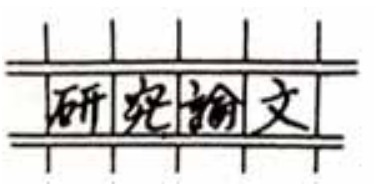

\title{
Nd:YAG レーザを用いたレーザ励起ブレイクダウン特性解析
}

\section{Laser-Induced Breakdown Analysis Using Nd: YAG Laser}

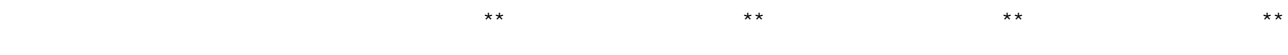
Terushige HORI , Fumiteru AKAMATSU , Masahiko SHIBAHARA , Daisuke MIYATA and Masashi KATSUKI

(Received July 14 , 2004)

\begin{abstract}
Influence of the laser beam characteristics on the laser-induced breakdown of air was studied. Energy needed for the breakdown was precisely evaluated from the transmitted laser energy from the breakdown area. As the laser beam characteristics was varied, the breakdown threshold was unexpectedly found to be increased when the narrowest pulse width ( $8 \mathrm{~ns}$ ) was used, and the threshold value was approximately $2.5 \mathrm{~mJ}$ under a focusing lens of $\mathrm{f}=100 \mathrm{~mm}$. In addition, the aberration of the lens is found to be an important factor for the breakdown threshold when the laser-induced breakdown is performed under the lens having a short focal length, such as $\mathrm{f}=50 \mathrm{~mm}$.
\end{abstract}

Key Words: Laser-Induced Breakdown, Pulse Width, Breakdown Threshold, Aberration

\section{1. はじめに}

ガスタービンや自動車のエンジンといった内燃機関では， 低 NOx 化，高効率化のために希薄予混合燃焼方式が採用さ れている。希薄予混合燃焼方式は通常の燃焼と比べて火炎温 度が低く，局所的な高温領域の生成が抑えられることから， 燃焼中の NOx の発生量が少なくなるという利点を有してい る。しかし，希薄可燃限界に近づくにつれて燃焼速度が小さ くなり，わずかな熱損失や流れ場中の乱れのために燃焼か継 続しなくなり消炎してしまう。

われわれはレーザ励起ブレイクダウン ${ }^{1-6)}$ による可燃性予 混合気の着火について研究を行ってきたた ${ }^{7,8)}$ 。レーザ励起ブレ イクダウン (以下ブレイクダウンと記す) は高出カのレーザ 光パルス（以下，パルス光と記す）を集光することにより， 集光位置付近でプラズマが形成されるという現象である。ブ レイクダウンを用いた可燃性予混合気の着火は,パラメータ の調整が容易なこと,着火の位置やタイミングを任意に設定 できるため，燃焼容器の壁面や電気プラグによる熱の損失を 軽減できること，着火点数を増やすことが可能であり，燃焼 容器内において燃焼か完了するまでの時間か短縮できること， 燃焼容器の外からパルス光を入射・集光するだけで着火が行 えるため, 燃焼容器内に電気プラグが不要となり, 電気プラ グの劣化口交換の心配が不要となることなど，従来広く内燃 機関において着火に用いられてきた電気プラグによるスパー
ク着火 ${ }^{9)}$ では見られない特長を有しており，希薄予混合燃焼 などの着火源として有望な選択肢の 1 つと考えられている。

本論文では,レーザ励起ブレイクダウンによる可燃性予混 合気の着火過程を解明するために ,ブレイクダウン現象の基 本特性を解析した結果について示す。特に,パルス光のプロ ファイルや集光レンズの焦点距離がブレイクダウン現象にお よぼす影響について検証を行った。

\section{2 実験装置}

実験装置の概略を Fig.1 に示す。レーザ光には Q スイッチ Nd:YAGレーザ (Spectra Physics 社製，PIV-400) の第 2 高調 波 (発振波長 $532 \mathrm{~nm}$, 最大出力約 $260 \mathrm{~mJ} /$ pulse) を用いた。 パルス光は初期ビーム径が約 $8 \mathrm{~mm}$, パルス幅か約 $8 \mathrm{~ns}$, 繰り

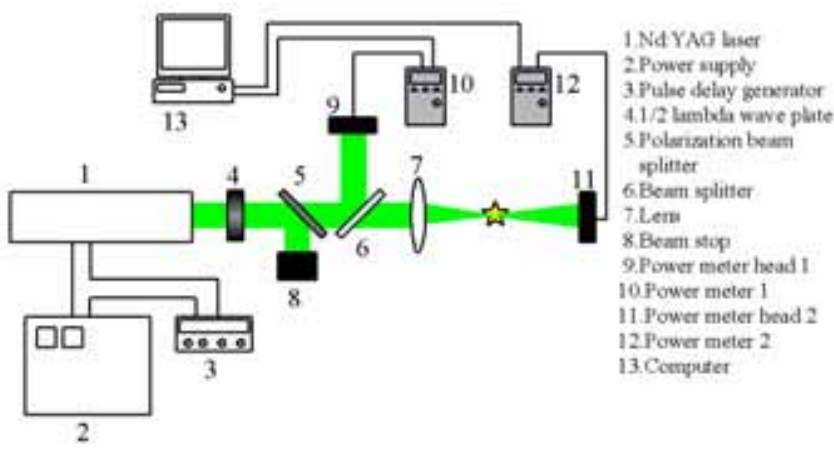

Fig.1 Experimental set-up for laser-induced breakdown.

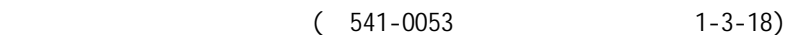

Forensic Science Laboratory, Osaka Policel1-3.18 Honmachi, Chuo-ku, Osaka, Osaka 541.0053, Japan)

$* *$ 大阪大学大学院工学研究科機械物理工学専攻 $\mid$ \% 565.0871 大阪府吹田市山田丘 2.1)

Department of Mechanophysics Engineering, Osaka University(2.1 Yamadaoka, Suita, Osaka 565.0871, Japan) 
返し周波数が $10 \mathrm{~Hz}$ であり，パルスディレイジェネレータ (Stanford Research Systems 社製，MODEL DG535) からの TTL 信号により発振の制御を行った。レーザ本体から出力された パルス光は $1 / 2$ 波長板，偏光ビームスプリッタを通過し， 焦点距離が $\mathrm{f}$ の平凸レンズにより集光され，集光位置付近で ブレイクダウンが起きる。パルス光のエネルギーは焦電型エ ネルギーメータ (Ophir 社製，PE-50) を用いて集光位置の前 後2箇所で同時測定した。後述するブレイクダウンの閾値は, エネルギーメータによる測定値から計算で求めることができ る。パルス光の時間·空間プロファイルを測定する場合には, エネルギーメータに代えてピンフォトダイオード（エレクト ロオプティクステクノロジー社製，ET-2000 型) あるいは空 間プロファイラ (Ophir 社製，Beam Star) を置き，光れ艺れ 条件の変化による時間および空間プロファイルの変化を測定 した。

\section{3 パルス光のプロファイル}

パルス光の時間プロファイルを Fig.2 に示す。以下 , フラ ッシュランプの励起エネルギーが最大の場合をImax と記す。 また ,a Imax とは励起エネルギーが最大の場合 (Imax) に対 して,パルス光のエネルギーが光の $a$ 倍となるように励起エ ネルギーを調整した場合を示すものとする。パルス光の時間 プロファイルはピンフォトダイオード (エレクトロオプティ クステクノロジー社製， ET-2000 型) で検出し，デジタルス トレージオシロ (LeCroy 社製，LT264M) により出力した。

Fig.2に示すように，Imax 時にはパルス幅が $8 \mathrm{~ns}$ 程度 (HWHM) のガウシアン分布形状のパルス光が得られたが , 励起エネルギーを減少させるにつれて, 時間プロファイルが いびつとなり，パルス幅が広がっていくことがわかった。デ ジタルストレージオシロの時間分解能の関係で, 波形の凹凸 か強調された部分も見られるが , 0.1 Imax の場合でパルス幅 が $12 \mathrm{~ns}$ 程度であった。

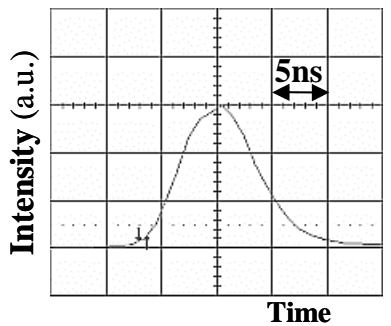

(a) Imax

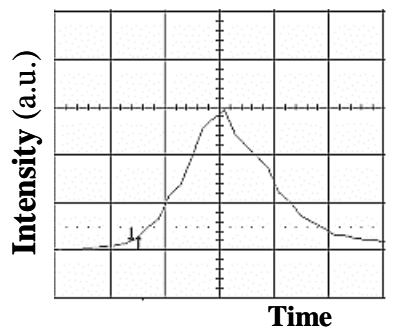

(c) 0.33Imax

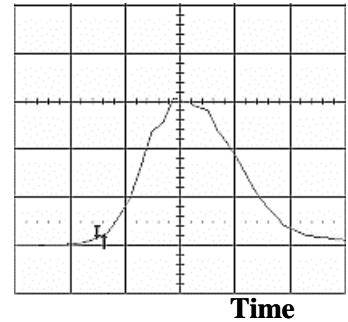

(b) 0.5Imax

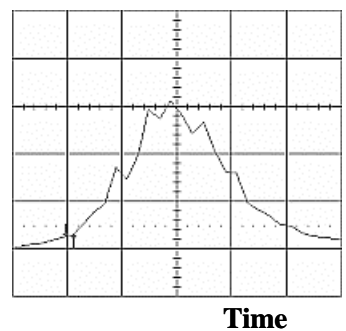

(d) 0.1Imax
Fig.2 Nd:YAG laser temporal profiles.

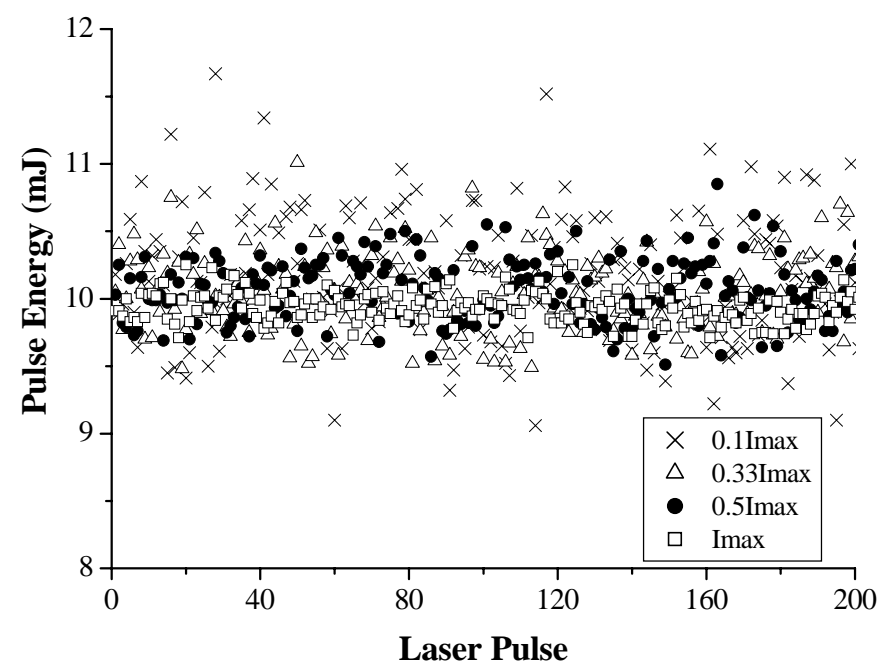

Fig.3 Stability of laser pulse energy $(E=10 \mathrm{~mJ})$.

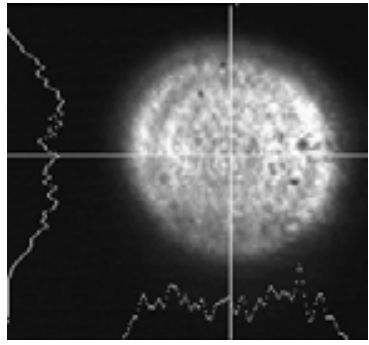

Imax

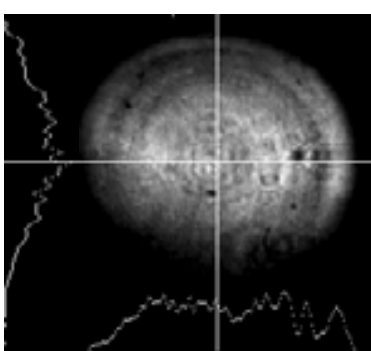

0.3Imax

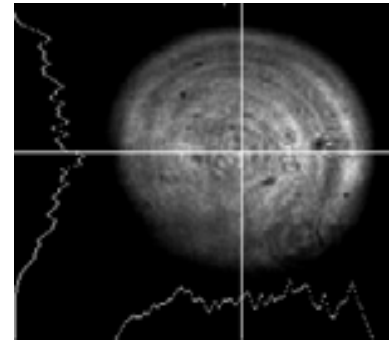

0.5Imax

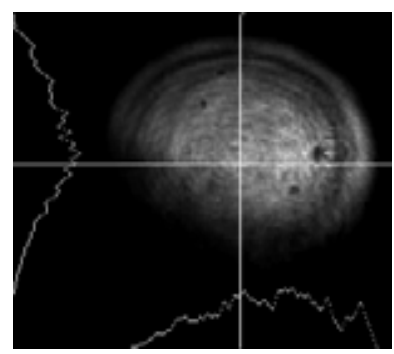

0.1 Imax
Fig.4 Spatial profiles of Nd:YAG laser pulse.

Table 1 Spatial Profile of Nd:YAG laser pulse - correlation to Gaussian profiles.

\begin{tabular}{|c|c|c|}
\hline & Horizontal \% & Vertical \% \\
\hline 0.1 Imax & 80.3 & 82.7 \\
\hline 0.3 Imax & 72.1 & 78.9 \\
\hline 0.5 Imax & 69.1 & 78.6 \\
\hline Imax & 66.6 & 76.9 \\
\hline
\end{tabular}




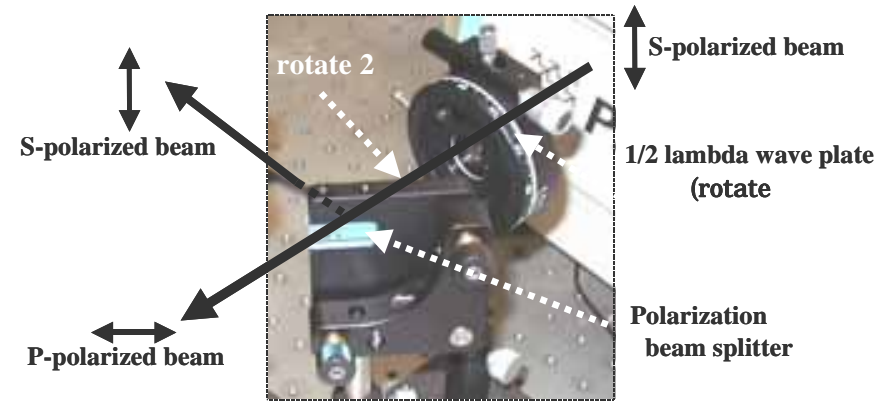

Fig.5 Laser pulse energy control system.

Fig.3にパルス光のエネルギー安定性を調べた結果につい て示す。図は励起エネルギーをパラメータとし ,パルス光の エネルギーを約 $10 \mathrm{~mJ}$ としたときのパルス光のエネルギー変 動を示している。横軸は測定したパルス光の番号を示し，レ 一ザが $10 \mathrm{~Hz}$ で発振していたことから，Fig.3では各励起エネ ルギーにおいて 20 秒間 (200 発) のパルス光のエネルギー 安定性を評価していることになる。Fig.3に示すように,Imax の場合に変動幅が最も狭く (Imax : $\pm 3 \%)$, 励起エネルギー を小さくしていくにしたがって ,レーザの発振が不安定とな り,パルスごとのエネルギーの変動幅が広がっていることが わかる (0.1Imax : $\pm 10 \%)$ 。

Fig.4 に励起エネルギーを変化させたときのパルス光の空 間プロファイル,およびビームの中心位置における垂直方向 および水平方向のビーム強度プロファイルを示す。また，

Table1 に各励起エネルギーにおける理想的なガウシアン分 布曲線に対する相関係数を示す。

本実験で使用した Nd:YAGレーザは, YAG レーザロッド の励起エネルギーが最大のときに出力が最大となり，パルス 光の空間プロファイルがトップハット状となった。ここでト ップハット状のプロファイルとは ,ビームの中心付近を含め て広い範囲でほぼ同じような強度を持ち,ビーム端付近で急 激にビームの強度が低下するような強度分布のことを示して いる。パルス光の空間プロファイルは励起エネルギーを Imax から減少させていくにしたがって，トップハット状のプロフ アイルからガウシアン分布に近づいていき,理想的なガウシ アン分布曲線に対する相関係数が高くなっていくことか確認 された。このトップハット状の強度分布は, Nd:YAGレーザ を加工用に使用する場合などに有効なプロファイルと考えら れるが, エネルギーの効率化を目的として, ブレイクダウン 閾値をできるだけ低くしたい場合には，集光位置付近でのエ ネルギー密度を高くするために,ガウシアン分布に近い空間 プロファイルを持つようにレーザ内の光学系などの調整を行 って実験することが望ましい。

励起エネルギーの増減によりパルス光のエネルギーを調整 する場合, 得られるパルス光のプロファイルは上述のように 励起エネルギーの増減にともない変化してしまう。光こで， 本研究では Fig.5 に示すような $1 / 2$ 波長板と偏光ビームス プリッタを用いて ,レーザ本体の後段でパルス光エネルギー
の調整を行った。パルス光エネルギーの調整方法は以下に示 す通りである。

レーザ本体から出力されたパルス光はまず $1 / 2$ 波長板に 入射され, 垂直方向に直線偏光しているパルス光の偏光方向 が回転される。回転角度は $1 / 2$ 波長板の角度に応じて決ま り，1/2 波長板を通過する際に偏光方向が回転される。偏 光ビームスプリッタでは $1 / 2$ 波長板を通過してきたパルス 光のうち, 水平方向に偏光している成分のみが透過する。つ まり，1／2 波長板によりパルス光の偏光を回転させること で, 偏光ビームスプリッタを透過するエネルギーの調整が可 能となる。この $1 / 2$ 波長板と偏光ビームスプリッタの組み 合わせを採用したことで, Nd:YAGレーザのビームプロファ イルを変えることなく,パルス光のエネルギーの調整が行え るようになった。

4 レーザ励起ブレイクダウンについて

(1) ブレイクダウンメカニズム ${ }^{1,2,10)}$

ブレイクダウンによるプラズマの形成にはおもに2つの過 程が関与している。すなわち, 多光子吸収過程とカスケード 過程である。

多光子吸収過程は波長が短く,エネルギーの十分高いパル ス光が集光された場合に，集光位置付近に存在する分子や原 子か数個の光子を同時に吸収して自由電子が形成されるとい うもので，この過程は次式で表される。

$$
\mathrm{M}+\mathrm{mhv} \rightarrow \mathrm{M}^{+}+\mathrm{e}^{-}
$$

ここで, $\mathrm{e}^{-}$は自由電子, $\mathrm{M}$ は中性粒子, $\mathrm{m}$ が吸収される光 子の数, hv が光子の持つエネルギーである。

多光子吸収過程の場合は nhv がイオン化エネルギーより も大きくなる最低の数 nだけ光子が同時に中性粒子に衝突し なければイオン化は起こらない。したがって , 波長が長くな るほどイオン化には多くの光子が必要となる。空気中の酸素

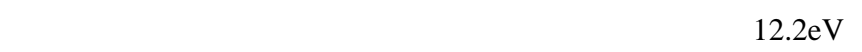
$15.6 \mathrm{eV}$ であるため ${ }^{10)}$ ，たとえば Nd:YAG レーザの第 2 高調 波 $(\lambda=532 \mathrm{~nm}: \mathrm{hv}=2.36 \mathrm{eV})$ を使用した場合, 光れ光れ 6 個および7個の光子が同時に衝突しなければ各分子をイオン 化することはできない。

一方, カスケード過程とは自由電子が逆制動輻射を通じて 光のエネルギーを吸収して加速され，中性粒子やイオンに衝 突を繰り返すことにより,自由電子の密度が時間とともに急 激に増加するというもので, この過程は次式で表される。

$$
\mathrm{e}^{-}+\mathrm{M} \rightarrow 2 \mathrm{e}^{-}+\mathrm{M}^{+}
$$

ここで， $\mathrm{e}^{-}$は自由電子，M は中性粒子を表す。空気中で力 スケード過程によりブレイクダウンを起こすためには ,まず 初期の段階でカスケード過程を引き起こすための自由電子が 多光子吸収過程により集光位置付近に形成されていなければ ならない。光して，この自由電子が逆制動輻射を通じて光の エネルギーを吸収しながら加速され, 次々と中性粒子に衝突 
Nd:YAGレーザを用いたレーザ励起ブレイクダウン特性解析 (堀・赤松・芝原・宮田・香月)

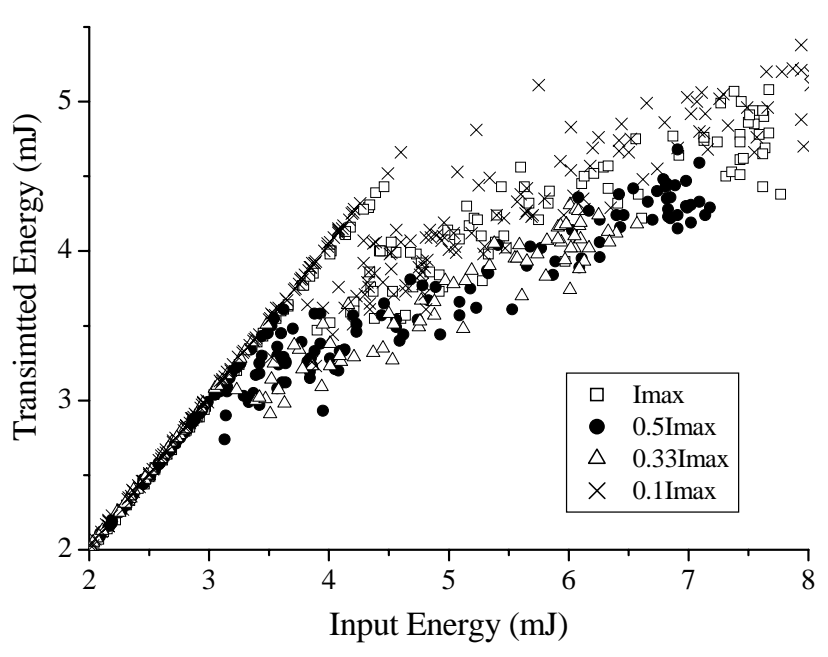

Fig.6 Flash lamp energy dependence of breakdown threshold ( $\mathrm{f}=100 \mathrm{~mm})$.

する。自由電子は壁面などに衝突して失括するものもあるが， エネルギーが十分であれば自由電子の数は時間とともに指数 関数的に増加し,閾値を超えた段階でブレイクダウンが起き ることになる。

ブレイクダウンはパルス光のパルス幅や雰囲気の圧力など， 条件によって多光子吸収が支配的な場合と,カスケード過程 が支配的な場合とがあり,両者では異なるパラメータ依存性 を示す ${ }^{1,2)}$ 。本実験のように，常温常圧でns オーダーのパル ス光を使用してブレイクダウンの実験を行った場合には,カ スケード過程が支配的となる。

（2）ブレイクダウン閾値の励起エネルギー依存性

Fig.6 に Nd:YAG レーザの励起エネルギーをパラメータと して , 入射光パルスのエネルギー (以下 , 入射光エネルギー と記す) と集光位置を透過してきたパルス光のエネルギー(以 下，透過光エネルギーと記す)を測定した結果について示す。 集光レンズには焦点距離 $\mathrm{f}=100 \mathrm{~mm}$ の平凸レンズを用いた。 ここで, ブレイクダウン閾值とは約 $50 \%$ の確率でブレイク ダウンが起きる入射光エネルギーとした。

Fig.6において, 入射光エネルギーが少なく，ブレイクダ ウンが起きないような範囲では,入射した光が光のまま集光 位置を透過するため, 入射光エネルギーと透過光エネルギー の間には線形関係が成立する。しかし，入射光エネルギーを 増加してブレイクダウンが起きると，入射光エネルギーの一 部がプラズマや衝撃波の形成などに消費されるため, 入射光 エネルギーと透過光エネルギーとの間にはもはや線形関係が 成立しなくなる。

Fig.6に示すように ,励起エネルギーを Imax としたときの ブレイクダウン閾値は約 $4.4 \mathrm{~mJ}$ であった。光して, 励起エネ ルギーを Imax から減らしていくとブレイクダウン閾值が低 くなり 励起エネルギーが $0.5 \mathrm{Imax}$ のときに約 $3.6 \mathrm{~mJ}, 0.33 \mathrm{Imax}$

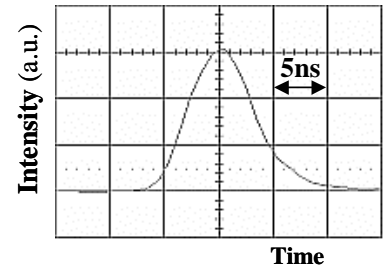

(a) $\mathrm{E}=\mathbf{2 . 2 \mathrm { mJ }}$

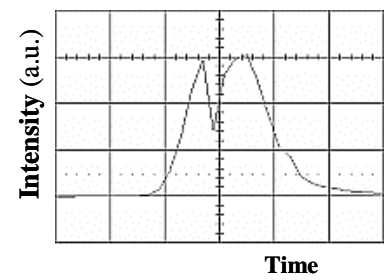

(c) $\mathrm{E}=29.5 \mathrm{~mJ}$

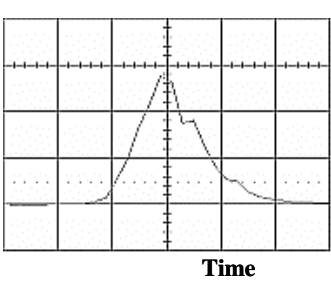

(b) $\mathrm{E}=5.1 \mathrm{~mJ}$

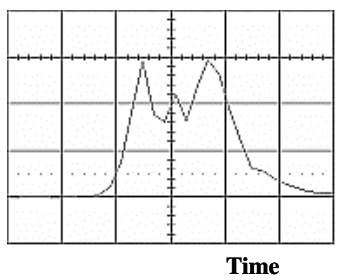

(d) $\mathrm{E}=75.9 \mathrm{~mJ}$
Fig.7 Temporal profile of transmitted pulse (Imax: $\mathrm{f}=100 \mathrm{~mm}$ ).

のときに約 $3.5 \mathrm{~mJ}$ となった。しかし，さらに励起エネルギー を下げることにより，逆にブレイクダウン閾值が高くなり， 励起エネルギーが 0.1Imax のときに約 $4.2 \mathrm{~mJ}$ となった。励起 エネルギーを下げたことによりブレイクダウン閾值が低くな ったのは, Fig.4 および Table 1 で示したように , 励起エネル ギーが Imax の場合にはトップハット状の空間プロファイル をしていたものが, 励起エネルギーを下げたことで空間プロ ファイルがガウシアン分布に近くなったことが原因の1つと して考えられる。つまり,同じエネルギーのパルス光を集光 しても，励起エネルギーを下げた方が集光位置付近でのエネ ルギー密度が高くなったためと考えられる。しかし, 励起エ ネルギーをさらに下げて 0.1Imax とした場合, 励起エネルギ 一が 0.33Imax の場合と比べてブレイクダウン閾値は高くな った。これは励起エネルギーを 0.1Imax まで下げるとレーザ 発振が不安定となり，ビーム中心付近においてはパルス光の 空間プロファイルがガウシアン分布に近づくものの,ビーム 全体としては空間プロファイルが悪くなったためであると考 えられる。

Fig.7 に励起エネルギーを Imax とした状態で，入射光エネ ルギーを変化させたときの透過光エネルギーの時間プロファ イルを示す。ここで集光レンズには焦点距離 $\mathrm{f}=100 \mathrm{~mm}$ の平 凸レンズを用いた。波形はパルス光 10 発の平均により得ら れたものであり，集光位置を透過してきた光に対して ND 減 光フィルタを挿入することで, 透過光エネルギーの最大值が ほぼ同じになるように調整を行った。ブレイクダウンが起き ると, 入射光エネルギーの一部か吸収され, 透過光エネルギ 一が減少する。ブレイクダウンによりプラズマが形成される 場合, エネルギーはプラズマの形成や衝撃波の発生などで消 費されるが, 入射光エネルギーが低いときには, ブレイクダ ウンが起きた場合でも透過光エネルギーの減少は光れほど大 きくなく ,パルスの後半部分で若干ェネルギーの減少が見ら れる程度であった。しかし , 入射光エネルギーの増加ととも に透過光エネルギーの減少が大きくなっていき,エネルギー 


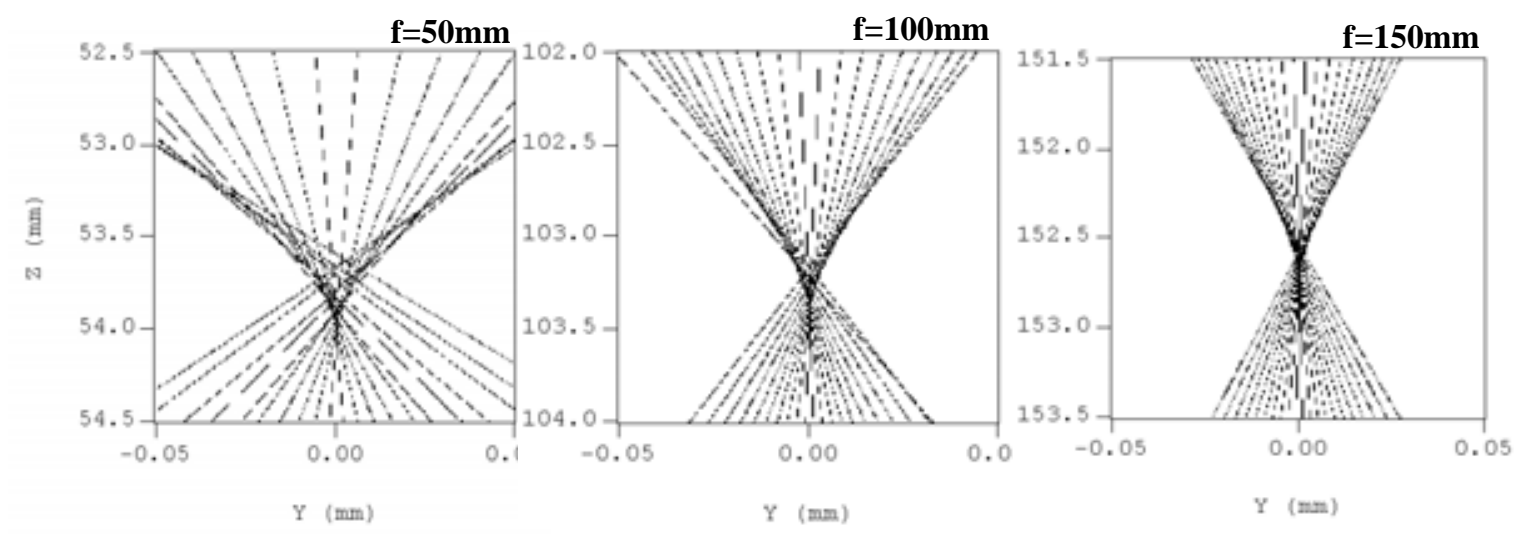

(a) $\mathrm{D}=8 \mathrm{~m} \mathrm{~m}$

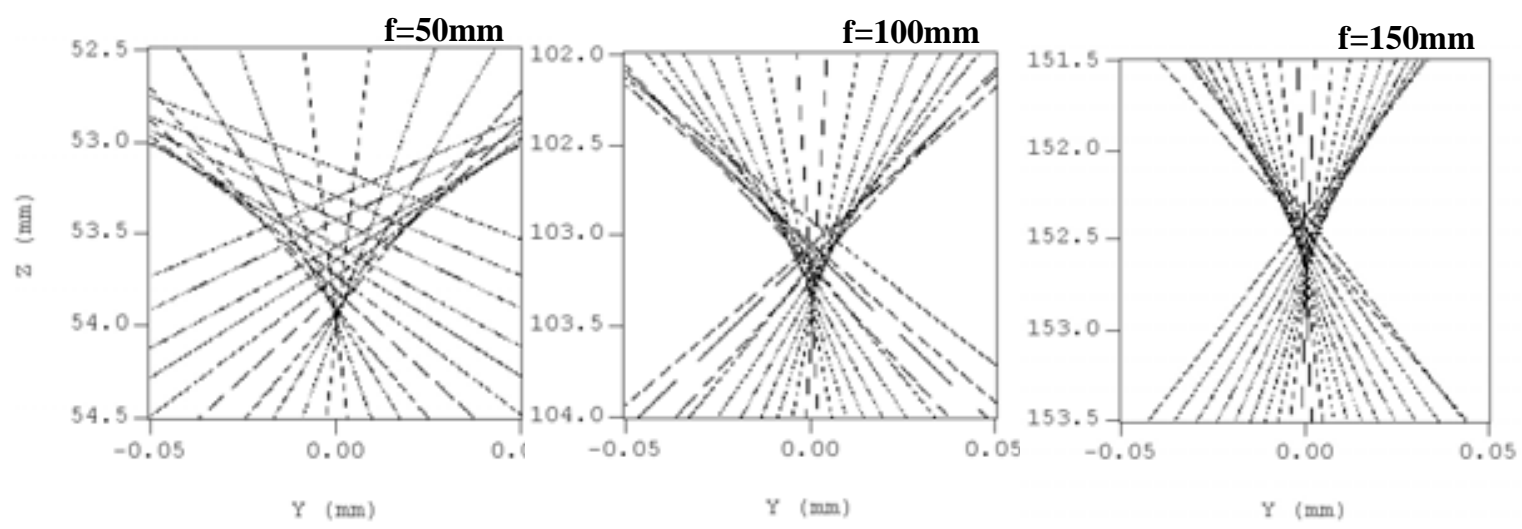

(b) $\mathrm{D}=12 \mathrm{~mm}$

Fig.8 Result of ray trace simulation: (a) $\mathrm{D}=8 \mathrm{~mm}$, (b) $\mathrm{D}=12 \mathrm{~mm}$.

\begin{tabular}{|c|c|c|c|}
\hline Focal length & $f=50 \mathrm{~mm}$ & $\mathbf{f}=100 \mathrm{~mm}$ & $\mathbf{F}=150 \mathrm{~mm}$ \\
\hline Lens dimeter & $40 \mathrm{~mm}$ & $50 \mathrm{~mm}$ & $50 \mathrm{~mm}$ \\
\hline Beam dimeter & $8 \mathrm{~mm}$ & $8 \mathrm{~mm}$ & $8 \mathrm{~mm}$ \\
\hline Beam profile & \multicolumn{3}{|c|}{ Uniform ligth } \\
\hline
\end{tabular}

(c) Simulation condition

Fig.8 Result of ray trace simulation.

の減少が始まる位置がパルスの前方に移動していった。これ は入射光エネルギーの増加により,パルス光の入射からブレ イクダウンが起きるまでの時間が短くなったためと考えられ る。

ブレイクダウンの特性を評価する場合,パルス光のプロフ アイルが測定条件により変化することは望ましいとはいえな い。1/2 波長板と偏光ビームスプリッタの使用により，レ 一ザ本体の後段でパルス光のエネルギー調整か行えることは， ブレイクダウンの特性を評価するためには非常に有効な手段 であると考えられる。
（3）ブレイクダウン閾値の焦点距離依存性

集光位置付近のパルス光のエネルギー密度は集光レンズの 焦点距離 $\mathrm{f}$ よび集光レンズに入射してくるパルス光の初期 ビーム径 D に依存する。すなわち, 収差のない理想的な結 像光学系として扱える近軸領域では，集光位置でのビームウ エスト径 dを

$$
d \propto f \lambda / D
$$

と表すことができる。ここでィははーザ光の波長を示す。集 光位置付近のエネルギー密度はビームウエスト径 $\mathrm{d}$ の 2 乗に 反比例することから，式(3)より $\mathrm{D} / \mathrm{f} の 2$ 乗に比例すること になる。つまり，近軸領域においてはパルス光の初期ビーム 径 $\mathrm{D}$ が大きいほど，焦点距離 $\mathrm{f}$ の短い集光レンズほど，集光 位置付近でのエネルギー密度を上げることができ,ブレイク ダウン閾値を低くすることが可能となる。

Fig.8 に $\mathrm{f}=50 \mathrm{~mm}, \mathrm{f}=100 \mathrm{~mm}, \mathrm{f}=150 \mathrm{~m}$ mの平凸レンズを用 いて光線追跡を行った結果について示す。Fig.8(a)が初期ビ 一ム径 D=8mm とした場合 ,Fig.8(b)が初期ビーム径 D=12mm とした場合の結果を示している。また, 光線追跡に用いた集 
光レンズの諸条件について Fig.8(c)に示す。ここで, 図の上 下方向がレーザ光軸 (Z 軸) を示し, 光は上方から下方へ伝 播していくものとする。光軸と直交する軸として Y 軸を取 った。図でレーザ光は均一な強度分布を持っているものとし， 線密度が高い部分ほどエネルギー密度が高くなっていること を示している。

Fig.8(a)および Fig.8(b)に示すように , 3 種類の平凸レンズ の中では焦点距離が短い $\mathrm{f}=50 \mathrm{~mm}$ を用いた場合が最も球面 収差の影響を受け，外側の光線の多くが集光位置手前で光軸 と交差したあと発散してしまうため，焦点位置付近のエネル ギ一密度が低くなっている。また, 初期ビーム径が $\mathrm{D}=12 \mathrm{~mm}$ の方が初期ビーム径 $\mathrm{D}=8 \mathrm{~mm}$ よりも球面収差が大きく，特 に, 焦点距離の短い $\mathrm{f}=50 \mathrm{~mm}$ の場合に乥の影響を強く受け， 集光位置付近で光線か集まらずに広がっていることがわかる。 これに対して, 焦点距離 $\mathrm{f}=100 \mathrm{~mm}$ および $\mathrm{f}=150 \mathrm{~mm}$ のレン ズでは, $\mathrm{f}=50 \mathrm{~mm}$ よりも光線が集光位置付近に集まってお り,初期ビーム径 $\mathrm{D}=12 \mathrm{~mm}$ の場合でも $\mathrm{f}=50 \mathrm{~m} \mathrm{~m}$ ほど顕著な 球面収差の影響は見られなかった。

励起エネルギーを Imax とし, 集光レンズの焦点距離 $\mathrm{f}$ を 变えた場合の入射光エネルギーと透過光エネルギーの関係を Fig.9 に示す。ここで, Fig.9(a)がパルス光の初期ビーム径 $\mathrm{D}=8 \mathrm{~mm}$ とした場合，Fig.9(b)が D=12mm とした場合の結果 を示している。なお，本実験で用いた集光レンズは焦点距離 $\mathrm{f}=50 \mathrm{~mm}$ のレンズのみレンズ径 $\varphi=40 \mathrm{~mm}$ であり, 乥れ以外 の焦点距離 $\mathrm{f}=100 \mathrm{~mm}$ および $\mathrm{f}=150 \mathrm{~mm}$ のレンズについては レンズ径 $\varphi=50 \mathrm{~mm}$ のものを使用した。

実験の結果，初期ビーム径 $\mathrm{D}=8 \mathrm{~mm}$ のときのブレイクダウ ン閾値は, 集光レンズの焦点距離 $\mathrm{f}=50 \mathrm{~mm}, \mathrm{f}=100 \mathrm{~mm}$,

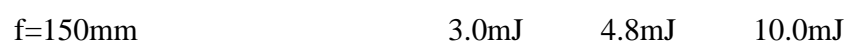
となり，焦点距離が短くなるほど低くなった。また，初期ビ 一ム径 $\mathrm{D}=12 \mathrm{~mm}$ の場合は 集光レンズの焦点距離が $\mathrm{f}=50 \mathrm{~mm}$ と $\mathrm{f}=100 \mathrm{~mm}$ のとき ブレイクダウン閾值が弚れ約 $2.7 \mathrm{~mJ}$ および約 $2.5 \mathrm{~mJ}$ とほぼ同じ值となり，f=150mm のレンズで は約 $6.4 \mathrm{~mJ}$ となった。

集光レンズの焦点距離を変えた場合のブレイクダウン閾値 の比は, 初期ビーム径 $\mathrm{D}=8 \mathrm{~mm}$ のとき $\mathrm{f}=50 \mathrm{~mm}, \mathrm{f}=100 \mathrm{~mm}$ ， $\mathrm{f}=150 \mathrm{~mm}$ でおよ光 $1: 1.6: 3.3$ となり，焦点距離が短くな るほどブレイクダウン閾值は低くなったが 球面収差の影響 がほとんどない近軸領域において, 式(3)から計算で求めた ブレイクダウン閾値の比( $1: 4: 9)$ と比べると, 特に焦点距 離の短い $\mathrm{f}=50 \mathrm{~mm}$ で計算值よりもブレイクダウン閾値が高 くなっていることがわかる。光線追跡の結果からもわかると おり，焦点距離の短いレンズは球面収差が大きいため収差の ない条件でパルス光を集光した場合と比べて, 集光位置付近 のエネルギー密度を高くすることができないと考えられる。 また，初期ビーム径 $\mathrm{D}=12 \mathrm{~mm}$ の場合について同樣にブレイ クダウン閾值の比を求めてみると,およ光 $1: 1: 2.5$ となり， 初期ビーム径を広げることて球面収差の影響がさらに強くな っていることがわかる。この場合も焦点距離の短い $\mathrm{f}=50 \mathrm{~mm}$
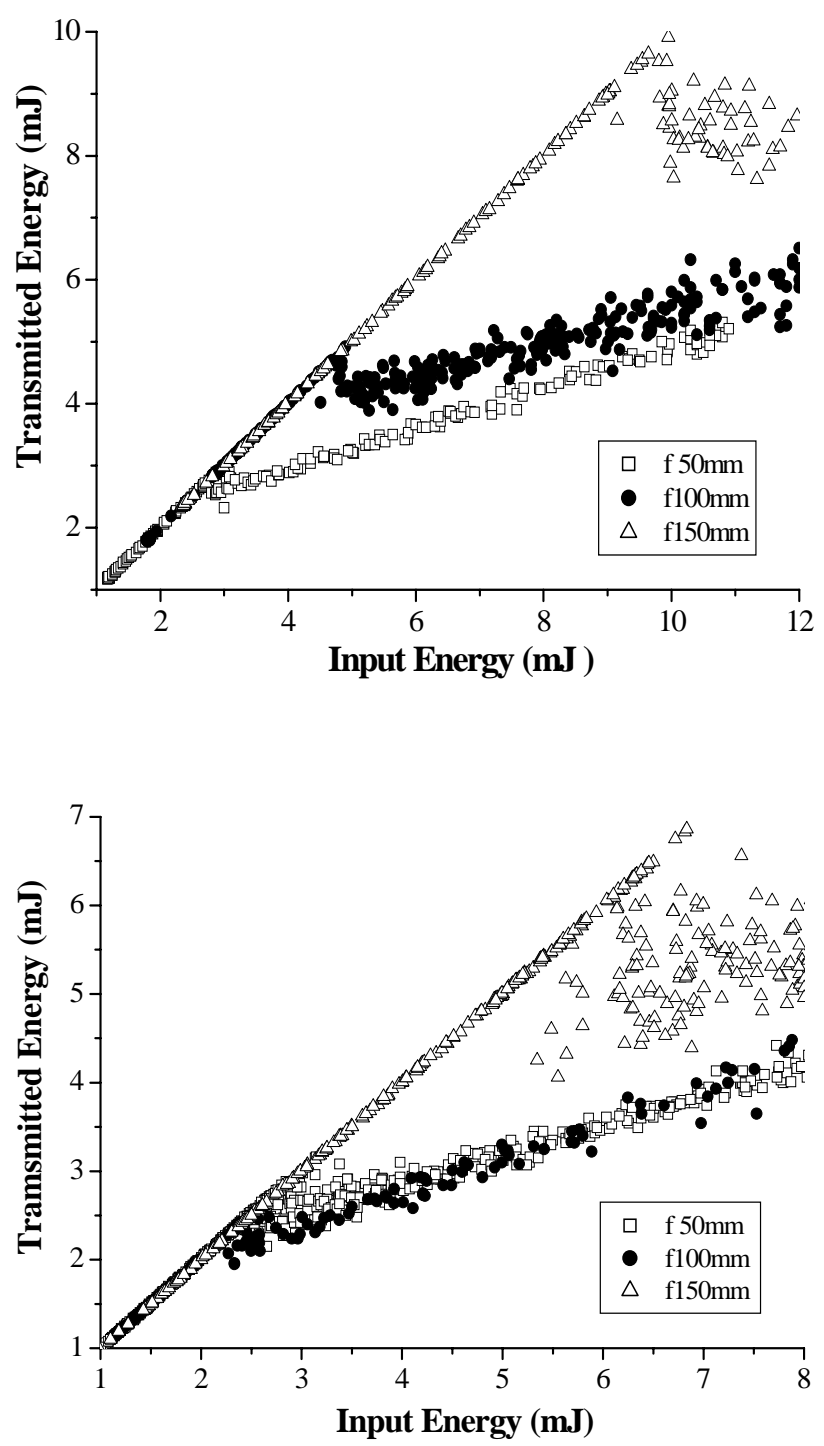

Fig.9 Focal length dependence of breakdown threshold:.

$\begin{array}{ll}\text { (a) } \mathrm{D}=8 \mathrm{~mm} & \text { (b) } \mathrm{D}=12 \mathrm{~mm}\end{array}$

のレンズでは初期ビーム径を広げたことによってブレイクダ ウン閾值が若干下がったのみであった。 $\mathrm{f}=100 \mathrm{~mm}, \mathrm{f}=150 \mathrm{~mm}$ のレンズでは,初期ビーム径を広げることによる球面収差の 影響はFig.8に示すように $\mathrm{f}=50 \mathrm{~mm}$ の場合ほど顕著ではなく， 初期ビーム径を $\mathrm{D}=8 \mathrm{~mm}$ から $\mathrm{D}=12 \mathrm{~mm}$ と広げることでブレ イクダウン閾值が低くなっていることがわかる。

Fig.9 に示すように, ブレイクダウン閾值付近では透過光 エネルギーに大きなばらつきが生じ,ブレイクダウン閾値が 高いほどそのばらつきの幅が大きくなっていることがわかる。 これはブレイクダウン閾值付近では,ブレイクダウンが起き るかどうかが, パルス光のエネルギーやプロファイル, 集光 領域内に存在するチリやゴミ (以下 , エアロゾルと記す) の 存在などで大きく変化するためと考えられる。すなわち, 集 光領域内にエアロゾルが存在することで,エアロゾルが核と なってブレイクダウンが起きると考えられるが ,ブレイクダ 
ウン閾值やブレイクダウンにより消費されるエネルギーがエ

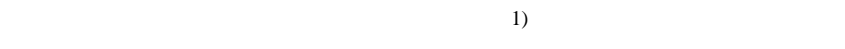
ネルギーやプロファイルの微妙な変化がブレイクダウン特性 に大きく影響するものと考えられる。なお，平均径 $50 \mu \mathrm{m}$ の粒子が存在することでエアロゾルがない場合と比べて ,ブ レイクダウン閾値が 2 から 3 桁下がるという報告がされてい $ろ^{11)}$ 。

\section{5 まとめ}

Nd:YAGレーザを用いたレーザ励起ブレイクダウンの基礎 特性について評価を行った。以下に得られた結果を要約する。 (1) Nd:YAGレーザにおいて, 励起エネルギーを変化させる ことによりパルス光の時間・空間プロファイルか変化し,ブ レイクダウン閾值に変化が見られることがわかった。

(2) Nd:YAGレーザはフラッシュランプの励起エネルギーを 最大にしたときに出力が最大となり，トップハット状の空間 プロファイルとなっているが, 励起エネルギーを減少させる ことで, プロファイルがガウシアン分布に近づき, 励起エネ ルギーを最大にした場合よりもブレイクダウン閾值が低くな る場合もあることがわかった。

(3) 収差のない理想的な結像光学系として扱える近軸領域 では, ブレイクダウン閾值は焦点距離 $\mathrm{f}$ が短いほど ,レーザ 光の初期ビーム径 D が大きいほど低くなる。しかし, 本実 験て使用した測定条件ではもはや近軸領域で取り扱うことは できず，球面収差の影響を受けることがわかった。光して，
球面収差の影響は焦点距離 $\mathrm{f}$ が短いほど, 初期ビーム径 $\mathrm{D}$ が大きいほど強いことが確認された。

\section{謝 辞}

本研究を行うにあたり,大変有益な二議論とこ助言をいた だきました大阪市立大学の細田 誠 教授に深く感謝申し上げ ます。

$$
\text { 参 考 文 献 }
$$

1) G.M.Weyl : Physics of Laser-Induced Breakdown : An update, in Laser-induced plasmas and applications, (Radziemski L.J. and Cremers D.A., Eds), Marcel Dekker. New York and Basel, 1989, 1.

2) C.G.Morgan : Rep. Prog. Phys. 38 (1975) 621.

3) Y.-L.Chen, J.W.L.Lewis and C.Parigger : J. Quantitative Spectroscopy \& Radiative Transfer, 66 (2000) 41.

4) Y.-L.Chen, J.W.L.Lewis and C.Parigger : J. Quantitative Spectroscopy \& Radiative Transfer, 67 (2000) 91.

5) T.X.Phuoc, and F.P.White Combust. Flame, 119 (1999) 203.

6) T.X.Phuoc, Combust. Flame, 122 (2000) 508.

7) 堀ほか : 第 40 回燃焼シンポジウム講演論文集 , 479 (2002) 480.

8) 堀ほか : 第 40 回燃焼シンポジウム講演論文集 , 481 (2002) 482.

9) B.Lewis and G. von Elbe : Combustion, Flames and Explosions of Gases (3rd ed.) Academic press, New York, (1987) 215.

10) 堤井信力 : プラズマ基礎工学, (1995).

11) P.G.Pinnik, et al., Appl. Opt., 27 (1988) 967. 